\title{
QUANTITATIVE ASSESSMENT OF DYNAMICS OF ECONOMIC DEVELOPMENT IN THE COUNTRIES OF THE EUROPEAN UNION
}

\author{
Rita REMEIKIENE் (D) ${ }^{*}$, Jaroslav BELAS (D)2, \\ Tomas KLIESTIK ${ }^{3}$, Lubos SMRCKA (D) 4 \\ ${ }^{1}$ Public Safety Academy, Mykolas Romeris University, Vilnius, Lithuania \\ ${ }^{2}$ Faculty of Economics and Management, Tomas Bata University in Zlín, Zlín, Czech Republic \\ ${ }^{3}$ Faculty of Operation and Economics of Transport and Communication, \\ University of Žilina, Žilina, Slovakia \\ ${ }^{4}$ Faculty of Business Administration, University of Economics Prague, Prague, Czech Republic
}

Received 19 November 2019; accepted 08 April 2020

\begin{abstract}
The European Union is made up of countries that differ significantly in their economic development. In order to develop tailored strategies for their development, it should be possible to quantify the condition at a desired point in particular time. Again, on this basis, the process of economic development can be quantified and thus typicalities identified. The process is characterized by several parameters: intensity, which reflects the quantitative side of the development process; homogeneity reflecting upon the qualitative side of the development process, and dynamics, integrating development intensity and homogeneity into one generalizing mean. The values of the economic development process make it possible to divide all the countries of the European Union into three levels. This distinction allows for a differentiated analysis of the effects of economic development of countries in terms of their social, environmental and other development.
\end{abstract}

Keywords: sustainable development, EU, quantitative assessment, GDP per capita.

JEL Classification: Q01, C00.

\section{Introduction}

The construction of the European Union (EU) as a political, economic and administrative community dates back 60 years and is not yet over. As a result, its composition is very uneven. Depending on the level of economic development, three groups of countries could be relatively distinguished. The first group would be made of the most economically advanced members of the EU, which were admitted to the Community before 1995. The second group includes a large number of Central and Eastern European countries, which became members

*Corresponding author. E-mail: rita.remeikiene@mruni.eu

This is an Open Access article distributed under the terms of the Creative Commons Attribution License (http://creativecommons. org/licenses/by/4.0/), which permits unrestricted use, distribution, and reproduction in any medium, provided the original author and source are credited. 
in 2004. The third group could include the latest adopted countries. They are characterized by a gap in economic development from the countries belonging to the second - and even more so - the first group.

Economic development is the basis for the well-being of both the individual country and the community as a whole, and it is important to notice the patterns of this development. This would help to formulate further targeted development strategies that take into account the level of economic development achieved by the countries. Research object - sustainable development.

Disclosure of regularities is possible if there is a way to quantify the state of the development process at a desired point in time, and to predict the sequence of changes on that basis. First of all, it is necessary to determine which indicator or indicators reflect upon the economic development of the country. Based on this, it will be possible to analyze the changes, identify the components of this complex process, their interdependencies, and so on. The key requirement for an economic development indicator or indicators is that they allow $\mathrm{c}$ need to allow making comparisons between particular EU countries in different ways. In this way, countries could be differentiated according to their economic development, in order to formulate differentiated development strategies.

\section{The indicator of country's economic development is the gross domestic product per capita}

The economic development of the countries is subject to multi-layered complex processes which, in reality, manifest themselves in many different ways. The quantification of such phenomena can only be achieved by indicators, indices or their systems that can combine all these aspects into one aggregated measure.

Bibliography and international practice have raised two approaches to quantifying the status of such complex processes. In the first case, it is suggested to use one indicator that integrates the performance of all economic activities of the country (industry, construction, transport, agriculture, services, etc., i.e. those that create added value) (Čiegis et al., 2010; Babu \& Dutta, 2015). In the second case, the overall process of economic activity is broken down into separate parts (Parris \& Kates, 2003; Čiegis et al., 2010; Rotmans, 2006; Spangenberg, 2012; Scherp, 1994; Wackernagel \& Rees, 1996; McLaren et al., 1998; Hamilton, 2007). Each of these parts represents a system of indicators. These systems quantify the condition of each part. The overall result is obtained by combining the evaluations of the parts in one way into a single summation (Kareivaite, 2012; Janker \& Mann, 2018; Strezov et al., 2017; Kondyli, 2010; Compagnolo et al., 2018; Turan, 2013; Radovanovic \& Lior, 2017; Zinatizadeh et al., 2017; Touceda et al., 2018; Rametsteiner et al., 2011; Schoenaker et al., 2015; Ginevičius et al., 2018; Gedvilaite, 2019).

In the first case, the measure of economic development quantifies and uses gross domestic product per capita (GDP) (Van den Beryh, 2009). The second case is based on multi-criteria assessment methods (Song et al., 2017; Pehlivan et al., 2018; N. Prascevic \& Z. Prascevic, 2017; Turskis et al., 2017; Boggia \& Cortina, 2010; Gedvilaite, 2019).

It is possible that the second way of quantifying the state of economic development is more accurate than the first. This is because the overall development process is broken down 
into the desired number of dimensions. This gives a fairly adequate picture of the phenomenon under consideration. By giving these aspects specific quantitative expressions, i. e. formalizing them, indicator systems that fully reflect the phenomenon under consideration are being created. They provide a reasonably accurate quantification of the condition at the point in time.

On the other hand, deeper analysis reveals the reasons for limited applicability of this approach to assess the economic development of countries. There are several of the reasons. Firstly, in each country, due to its specificity, access to relevant information, and so on. economic development is reflected by indicator systems that differ from their counterparts in other countries, both in their composition and in their number (Wallis et al., 2011; Gzzebyk \& Stec, 2015; Graymore et al., 2010; Ivanovic et al., 2009; Delai \& Takahashi, 2011; Xavier et al., 2018; Wang et al., 2018; Sala et al., 2015). Secondly, the high cost of computation due to the fact that the importance of indicators that are difficult to formalize and the importance of system indicators can only be determined on the basis of expert judgment (Golusin et al., 2011; Boggia et al., 2014; Becker et al., 2017; Rogge, 2018; Zhou et al., 2010; Chowolhury \& Squire, 2006; Booysen, 2002). For these reasons, the results of the multi-criteria assessment cannot be used to compare economic development between countries.

Moreover, in all the proposed systems of economic development indicators, GDP is the most other important components (Mally, 2018; Jia et al., 2017; Bilan et al., 2019). Consequently, it is recognized as one of the most important indicators of the economic development. The fact that information on GDP is easily accessible and is made public in national or international statistical publications or databases (Eurostat, 2019) also speaks in favor of GDP. Gross Domestic Product per capita is calculated according to a unified methodology and thus becomes a universal indicator allowing comparisons between countries according to their level of economic development.

The main reason that GDP per capita to be used to measure countries' economic development is its complexity. It combines all economic performance, both sectoral and territorial. Therefore, it is not surprising that the amount of GDP adequately reflects upon the state of economic development of the country (Čiegis et al., 2010). Therefore, GDP per capita is taken as the indicator of economic development of EU countries in this study.

\section{Methodology for quantification of economics development in the countries of the European Union}

The economic development of countries is measured over a period of time, which consists of time spans. Time span is considered to be usually a year. The basis for assessment is the state of economic development over particular time periods. The totality of these conditions makes it possible to assess and analyze changes in economic development that have taken place over the period under review. They can be quite different: for some countries they can be quite noticeable, whereas for others economic development can undergo without significant fluctuations (see Figure 1).

Figure 1 shows that the situation of country's economic development can be characterized by four parameters: development intensity, uniformity, dynamics and duration of the period under consideration. The first three parameters are changeable and differ for each country, 
whereas the fourth parameter remains the same. Changeable parameters, in their sense, represent two different sides of the development process: intensity as quantitative changes, and uniformity as qualitative, whereas dynamics as the integral size of quantitative and qualitative changes. Based on this, a quantitative matrix of economic development of the country can be formed (see Table 1).

From Table 1 it is clear that three indicators of economic development - intensity, continuity and dynamics - can be calculated for each country. For each country, they are determined in two viewpoints - with or without assessing and evaluating the context of the other countries.

From Table 1 an important development trend can be identified. This will be the effect of the intensity of economic development on the sustainability of development.

In order to carry out such an analysis, in both cases it is necessary to have expressions of the indicators of intensity and uniformity of economic development and to calculate their values.

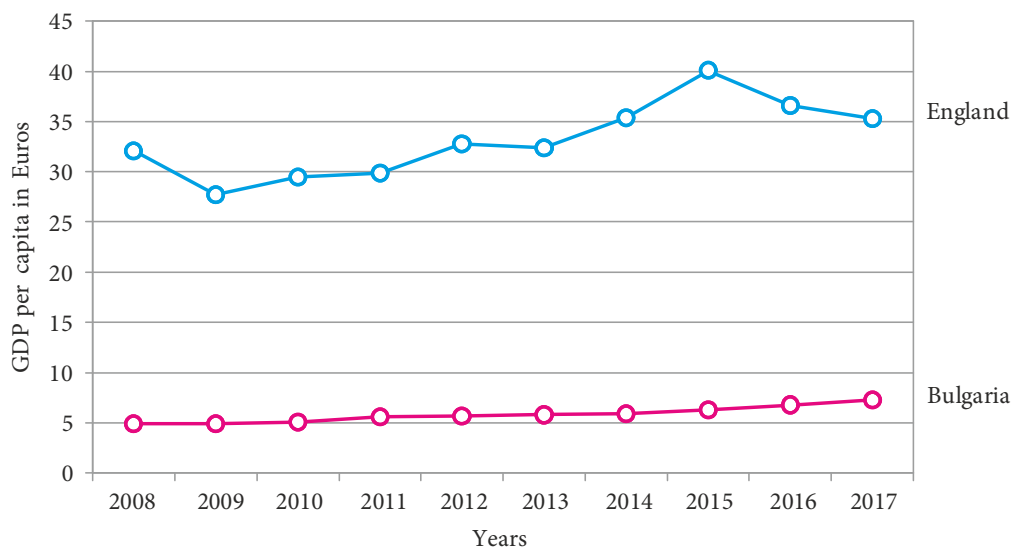

Figure 1. GDP per capita in England and Bulgaria (source: Eurostat, 2019)

Table 1. Matrix of quantitative assessment of national economic development (source: compiled by authors)

\begin{tabular}{|c|c|c|c|c|}
\hline \multirow{2}{*}{ Parameters of assessment } & quantitative & qualitative & complex \\
\hline \multirow{3}{*}{ Intensity } & One country & + & - & - \\
\cline { 2 - 5 } & $\begin{array}{c}\text { All countries' } \\
\text { context }\end{array}$ & + & - & - \\
\hline \multirow{3}{*}{ Uniformity } & One country & - & + & - \\
\cline { 2 - 5 } & $\begin{array}{c}\text { All countries' } \\
\text { context }\end{array}$ & - & + & + \\
\hline \multirow{2}{*}{ Dynamics } & One country & - & - & + \\
\cline { 2 - 5 } & $\begin{array}{c}\text { All countries' } \\
\text { context }\end{array}$ & - & - & + \\
\hline
\end{tabular}


The intensity of economic development for a particular country over a particular time span can be determined as follows (Ginevičius et al., 2018):

$$
D_{I j}^{T}=\frac{Q_{f j}^{T}}{Q_{b j}^{T}},
$$

where $D_{I j}^{T}$ is intensity of economic development of country $\mathrm{j}$ over the period $T$ considered; $Q_{f j}^{T}$ is economic development status of country $j$ at the end of period $T$; and $Q_{b j}^{T}$ is the same value at the beginning of period $T$.

The intensity of economic development of a country during the analyzed period $T$, while assessing the context of economic development in other EU countries as follows (Ginevičius et al., 2018) can be determined by the following formula:

$$
\tilde{D}_{I j}^{T}=\frac{Q_{f j}^{T}}{Q_{\min }^{T}},
$$

where $\tilde{D}_{I j}^{T}$ is the intensity of economic development of EU country $j$ during the period under consideration $T$, which assesses the economic development context of other EU countries; and $Q_{\min }^{T}$ is the value of the economic development indicator at the beginning of period $T$ for the EU country with the lowest level.

The uniformity of economic development of the EU countries during the analyzed period $T$ can be determined based on MDD methodology (Ginevičius et al., 2018). Its essence is the ratio of the value expressed as the total duration of the period under consideration, to the actual total length of the economic development trajectory:

$$
\begin{aligned}
& D_{T j}^{T}=\frac{T}{\sum_{i=1}^{n} \sqrt{1+\Delta q_{j i}^{2}}} ; \\
& \Delta q_{j i}=q_{j i+1}-q_{j i},
\end{aligned}
$$

where $D_{T j}^{T}$ is the measure of the uniformity of economic development of the EU country $j$ during the period under review $T ; \Delta q_{j i}$ - change in economic development of E country $j$ during the examined period $\mathrm{Ti}$ of the whole period considered; $q_{j i}$ - value of economic development of EU country $j$ at the beginning of period $T i$ of the period under consideration; $q_{j i+1}$ is thevsame value at the end of period Ti of the whole period under consideration; and $n$ is the number of time periods $(i=\overline{1, n})$ of the period $T$ under consideration.

By knowing how to calculate the intensity and sustainability indices of countries' economic development, it is possible to determine the level of development dynamics (Figure 2). The way in which this is determined depends on the importance of the intensity and continuity indicators for the dynamics of economic development. If it is not possible to be evaluated, the dynamics index can be calculated as follows (Ginevičius et al., 2018):

$$
\begin{aligned}
& D_{D j}^{T}=D_{I j}^{T} \times D_{T j}^{T} ; \\
& \tilde{D}_{D j}^{T}=\tilde{D}_{I j}^{T} \times D_{T j}^{T},
\end{aligned}
$$

where $D_{D j}^{T}$ is an indicator of the economic development dynamics of the particular EU co- 
untry $j$, especially when the economic development context of other EU countries is not possible to be considred; and $\tilde{D}_{D j}^{T}$ is the same value when this context is evaluated.

If the importance of the intensity and continuity of economic development as an indicator of development dynamics is assessed, it can be determined as follows:

$$
\begin{aligned}
& D_{D K j}^{T}=\omega_{1} D_{I j}^{T}+\omega_{2} D_{T j}^{T} ; \\
& \tilde{D}_{D K j}^{T}=\omega_{1} \tilde{D}_{I j}^{T}+\omega_{2} D_{T j}^{T},
\end{aligned}
$$

$D_{D K j}^{T}$ here is the indicator of the economic development dynamics of the EU country $j$, where the importance of development intensity and continuity to the dynamics of development is assessed; $\tilde{D}_{D K j}^{T}$ is the same value when assessing the context of other EU countries.

Based on the above methodology, a complex analysis of economic development of the EU countries was performed.

\section{Analysis of economic development in EU countries}

The analysis of the economic development of the EU countries is based on the basic table, which provides the GDP per capita values for 2008-2017. This means that the period under consideration $\mathrm{T}$ consists of ten time periods (years) (see Table 2).

Based on Table 1 and the formulas (1) to (3), the values $D_{I j}^{T}$, $\tilde{D}_{I j}^{T}$ and $D_{T j}^{T}$ were calculated (see Table 3).

From this table, it can be seen that the uniformity of the countries' economic development varies from 0 to 1 , while the range of intensity variation is open, i. e. it does not have a possible frame, and, therefore, has values greater than 1.0. In order to correctly calculate the rate of dynamics of economic development (formulas (5) to (8)), both quantities, namely, intensity and uniformity, must be comparable. This means that the indicator of economic development intensity must be transformed in an appropriate way so that it also varies between 0 and 1 . This procedure can be performed according to formulas (1) and (2) as follows:

$$
\begin{aligned}
& D_{I j}^{T T}=\frac{D_{j}^{T}}{D_{\max }^{T}} ; \\
& \tilde{D}_{I j}^{T T}=\frac{\tilde{D}_{j}^{T}}{\tilde{D}_{\max }^{T}},
\end{aligned}
$$

$D_{j}^{T T}$ here is the transformed value of the economic development intensity indicator of the EU country $j$ during the period $T$ under review for the EU country as a whole; e.g. not considering the economic development context of other EU countries; $\tilde{D}_{j}^{T T}$ is the same value in the context of the economic development of other EU countries; $D_{\max }^{T}$ is the value of the economic development indicator for the EU country with the largest size; $\tilde{D}_{\max }^{T}$ is the same for the EU country for which size $\tilde{D}_{I j}^{T}$ matters most.

Analogous to formulas (5)-(6), the indicator of economic development dynamics of the EU countries can be determined by using formulas (9)-(10). The calculation formulas will look like this:

$$
D_{D T j}^{T}=D_{T j}^{T} \times D_{I j}^{T T}
$$


Table 2. EU Gross Domestic Product per capita 2008-2017 (source: Eurostat, n.d.)

\begin{tabular}{|c|c|c|c|c|c|c|c|c|c|c|c|}
\hline \multirow{2}{*}{ No. } & \multirow{2}{*}{ Country } & \multicolumn{10}{|c|}{ Year } \\
\hline & & 2008 & 2009 & 2010 & 2011 & 2012 & 2013 & 2014 & 2015 & 2016 & 2017 \\
\hline 1 & Belgium & 33.1 & 32.3 & 33.5 & 34.5 & 35.0 & 35.3 & 35.8 & 36.6 & 37.6 & 38.7 \\
\hline 2 & Bulgaria & 4.9 & 4.9 & 5.1 & 5.6 & 5.7 & 5.8 & 5.9 & 6.3 & 6.8 & 7.3 \\
\hline 3 & Czekh & 15.5 & 14.2 & 14.9 & 15.6 & 15.4 & 15.0 & 14.9 & 16.0 & 16.7 & 18.1 \\
\hline 4 & Denmark & 44.0 & 41.9 & 43.8 & 44.5 & 45.5 & 46.1 & 47.1 & 48.0 & 49.2 & 50.8 \\
\hline 5 & Germany & 31.7 & 30.6 & 32.1 & 33.7 & 34.3 & 35.0 & 36.3 & 37.3 & 38.4 & 39.6 \\
\hline 6 & Estonia & 12.3 & 10.6 & 11.0 & 12.5 & 13.5 & 14.3 & 15.2 & 15.7 & 16.5 & 18.0 \\
\hline 7 & Ireland & 41.8 & 37.5 & 36.8 & 37.4 & 38.1 & 38.9 & 42.0 & 55.9 & 57.5 & 61.2 \\
\hline 8 & Greece & 21.8 & 21.4 & 20.3 & 18.6(p) & $17.3(\mathrm{p})$ & $16.5(\mathrm{p})$ & $16.4(\mathrm{p})$ & $16.4(\mathrm{p})$ & $16.4(\mathrm{p})$ & $16.7(\mathrm{p})$ \\
\hline 9 & Spain & 24.3 & 23.3 & 23.2 & 22.9 & 22.2 & 22.0 & 22.3 & 23.3 & $24.1(\mathrm{p})$ & $25.1(\mathrm{p})$ \\
\hline 10 & France & 31.0 & 29.9 & 30.7 & 31.5 & 31.8 & 32.1 & 32.4 & 33.0 & $33.3(\mathrm{p})$ & $34.2(\mathrm{p})$ \\
\hline 11 & Croatia & 11.2 & 10.5 & 10.5 & 10.5 & 10.3 & 10.3 & 10.2 & 10.6 & 11.2 & 11.8 \\
\hline 12 & Italy & 27.6 & 26.4 & 26.8 & 27.3 & 26.7 & 26.5 & 26.7 & 27.2 & 27.9 & 28.5 \\
\hline 13 & Cyprus & 24.2 & 23.1 & 23.3 & 23.2 & 22.6 & 21.0 & 20.7 & 20.9 & $21.7(\mathrm{p})$ & $22.8(\mathrm{p})$ \\
\hline 14 & Latvia & 11.2 & 8.8 & 8.5 & 9.8 & 10.8 & 11.3 & 11.8 & 12.3 & 12.8 & 13.9 \\
\hline 15 & Lithuania & 10.2 & 8.5 & 9.0 & 10.3 & 11.2 & 11.8 & 12.5 & 12.9 & 13.5 & 14.9 \\
\hline 16 & Luxembourg & 77.9 & 74.2 & 79.2 & 83.1 & 83.0 & 85.3 & 89.2 & 90.6 & 91.3 & 92,6 \\
\hline 17 & Hungary & 10.8 & 9.4 & 9.9 & 10.2 & 10.0 & 10.3 & 10.7 & 11.3 & 11.6 & 12.7 \\
\hline 18 & Malta & 15.0 & 14.9 & 15.9 & 16.4 & 17.1 & 17.9 & 19.5 & 21.4 & 22.3 & 23.8 \\
\hline 19 & Netherlands & 39.4 & 37.8 & 38.5 & 39.0 & 39.0 & 39.3 & 39.8 & 40.8 & $41.6(\mathrm{p})$ & $43.0(\mathrm{p})$ \\
\hline 20 & Austria & 35.3 & 34.5 & 35.4 & 37.0 & 37.8 & 38.2 & 39.0 & 39.9 & 40.8 & 42.1 \\
\hline 21 & Poland & 9.6 & 8.2 & 9.4 & 9.9 & 10.1 & 10.3 & 10.7 & 11.2 & 11.1 & 12.2 \\
\hline 22 & Portugal & 16.9 & 16.6 & 17.0 & 18.0 & 17.5 & 16.3 & 16.6 & 17.4 & 18.1 & $18.9(\mathrm{p})$ \\
\hline 23 & Romania & 7.1 & 6.1 & 6.2 & 6.5 & $6.6(\mathrm{p})$ & 7.2 & 7.6 & 8.1 & 8.6 & $9.6(\mathrm{p})$ \\
\hline 24 & Slovenia & $18.8(\mathrm{p})$ & 17.7 & 17.7 & 18.0 & 17.5 & 17.6 & 18.2 & 18.8 & 19.5 & 20.8 \\
\hline 25 & Slovakia & 12.2 & 11.8 & 12.4 & 13.1 & 13.4 & 13.7 & 14.0 & 14.6 & 15.0 & 15.6 \\
\hline 26 & Finland & 36.5 & 33.9 & 34.9 & 36.5 & 36.9 & 37.4 & 37.6 & 38.2 & 39.3 & 40.6 \\
\hline 27 & Sweden & 38.3 & 33.3 & 39.4 & 42.9 & 44.5 & 45.4 & 44.7 & 45.8 & 46.7 & 47.3 \\
\hline 28 & England & 32,1 & 27,7 & 29,5 & 29,9 & 32.8 & 32.4 & 35.4 & 40.1 & 36.6 & 35.3 \\
\hline 29 & Island & 34,3 & 29,5 & 32,5 & 34,1 & 35,7 & 37.3 & 40.9 & 47.3 & 55.9 & 63.2 \\
\hline 30 & Lichtenstein* & $:$ & $:$ & $:$ & $:$ & $:$ & 128.4 & 133.2 & $149.0(\mathrm{p})$ & 147.1(p) & $:$ \\
\hline 31 & Norway & 66.5 & 57.7 & 66.3 & 72.4 & 79.1 & 77.6 & 73.3 & 67.1 & 64.1 & 67.1 \\
\hline 32 & Switzerland & 49.3 & 50.2 & 56.1 & 63.7 & 65.0 & 64.1 & 65.3 & 74.0 & 72.4(p) & $:$ \\
\hline 33 & $\begin{array}{l}\text { Former } \\
\text { Republic of } \\
\text { Yougoslavia }\end{array}$ & $3.3(\mathrm{p})$ & 3.3(p) & $3.5(\mathrm{p})$ & $3.7(\mathrm{p})$ & $3.7(\mathrm{p})$ & $3.9(\mathrm{p})$ & $4.1(\mathrm{p})$ & 4.4(p) & $4.7(\mathrm{p})$ & : \\
\hline 34 & Albania & 3.0 & 3.0 & 3.1 & 3.2 & 3.3 & 3.3 & 3.5 & 3.6 & $3.7(\mathrm{p})$ & $4.0(\mathrm{p})$ \\
\hline 35 & Serbia & 4.6 & 4.2 & 4.1 & 4.6 & 4.4 & 4.8 & 4.7 & 4.7 & 4.9 & $5.2(\mathrm{p})$ \\
\hline
\end{tabular}

Note: * - data unavailable. 


$$
\tilde{D}_{D T j}^{T}=D_{T j}^{T} \times \tilde{D}_{I j}^{T T},
$$

where $D_{D T j}$ is the indicator of the economic development dynamics of the EU member state $j$ for a single country (without considering the economic development context of other EU countries) based on the transformed values; and $\tilde{D}_{D T j}$ is the same value in the context of the economic development of other EU countries.

The calculated dimensions and values $D_{I j}^{T T}, \tilde{D}_{I j}^{T T}, D_{D T j}$ and $\tilde{D}_{D T j}$ are shown in Table 3.

Based on the values of Table 3, it is possible to determine the impact of the intensity of economic development on its uniformity, as well as the degree of dynamics of economic development in the EU countries with and without assessing the importance of the intensity and uniformity of economic development. In the second case we need to know the weights of these indicators. According to the expert survey, the importance of the intensity of economic development of a country to dynamics is 70 per cent, and that of continuity - 30 per cent. The result can be considered to be logical, since the economic development fluctuations during the particular time spans of the period under consideration, i.e. short-term fluctuations do not affect the social or economic development of a country as much as the development intensity, which is of a long-term nature. In this case, formulas (7)-(8) of the integrated assessment of the dynamics of economic development in the EU countries will look like this:

$$
\begin{aligned}
& D_{D K j}^{T}=0,7 D_{j}^{T}+0,3 D_{T j}^{T} ; \\
& \tilde{D}_{D K j}^{T}=0,7 \tilde{D}_{j}^{T}+0,3 \tilde{D}_{T j}^{T} .
\end{aligned}
$$

The results of the calculations based on formulas (5), (6) and (11) to (14) are shown in Table 3.

When the values of the intensity and stability indicators of the economic development of the EU countries are known (Table 3), it is possible to determine the relationship between them. The correlation-regression analysis has shown that both with the non-estimation and the estimation of the context of the economic development of other countries while the intensity increases, integrity decreases (Figures 2 and 3).

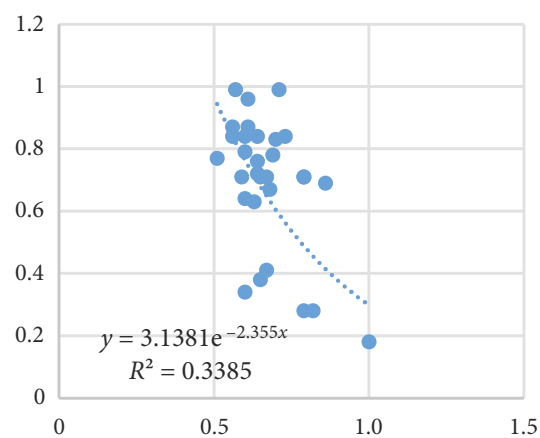

Figure 2. Results of the correlation-regression analysis on the impact of economic development intensity on ots integrity in EU when noncontextualising other countries applies (source: compiled by the authors)

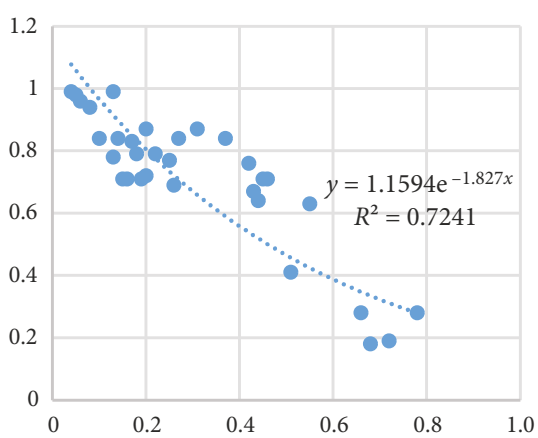

Figure 3. Results of correlation-regression analysis of the impact of economic development intensity on EU in the case when context of other countries is considered (source: compiled by authors) 
Table 3. Estimated values of indices of economic development of EU countries (source: compiled by authors)

\begin{tabular}{|c|c|c|c|c|c|c|c|c|c|c|c|c|}
\hline \multirow{2}{*}{ No } & \multirow{2}{*}{ Country } & \multicolumn{11}{|c|}{ Indices } \\
\hline & & $D_{I j}^{T}$ & $\tilde{D}_{I j}^{T}$ & $D_{T j}^{T}$ & $D_{I j}^{T T}$ & $\tilde{D}_{I j}^{T T}$ & $D_{D j}^{T}$ & $\tilde{D}_{D j}^{T}$ & $D_{D j}^{T}$ & $\tilde{D}_{D j}^{T}$ & $D_{D K j}^{T}$ & $\tilde{D}_{D K j}^{T}$ \\
\hline 1 & Belgium & 1.17 & 12.9 & 0.76 & 0.64 & 0.42 & 0.89 & 0.80 & 0.49 & 0.32 & 0.68 & 0.52 \\
\hline 2 & Bulgaria & 1.49 & 2.43 & 0.94 & 0.81 & 0.08 & 1.40 & 2.28 & 0.76 & 0.07 & 0.85 & 0.34 \\
\hline 3 & Czech & 1.17 & 6.03 & 0.72 & 0.64 & 0.20 & 0.84 & 4.34 & 0.46 & 0.14 & 0.67 & 0.36 \\
\hline 4 & Denmark & 1.15 & 16.93 & 0.63 & 0.63 & 0.55 & 0.72 & 10.67 & 0.40 & 0.35 & 0.63 & 0.58 \\
\hline 5 & Germany & 1.25 & 13.20 & 0.67 & 0.68 & 0.43 & 0.84 & 8.84 & 0.46 & 0.29 & 0.68 & 0.50 \\
\hline 6 & Estonia & 1.46 & 6.00 & 0.71 & 0.79 & 0.19 & 1.04 & 4.26 & 0.56 & 0.13 & 0.76 & 0.34 \\
\hline 7 & Ireland & 1.46 & 20.40 & 0.28 & 0.79 & 0.66 & 0.41 & 5.71 & 0,22 & 0.18 & 0.63 & 0.54 \\
\hline 8 & Greece & 0.77 & 5.57 & 0.79 & 0.42 & 0.18 & 0.61 & 4.40 & 0.33 & 0.14 & 0.69 & 0.37 \\
\hline 9 & Spain & 1.03 & 8.37 & 0.84 & 0.56 & 0.27 & 0.87 & 7.03 & 0.47 & 0.23 & 0.64 & 0.44 \\
\hline 10 & France & 1.10 & 11.40 & 0.84 & 0.60 & 0.37 & 0.92 & 9.58 & 0.50 & 0.31 & 0.67 & 0.51 \\
\hline 11 & Croatia & 1.05 & 3.93 & 0.99 & 0.57 & 0.13 & 1.04 & 3.89 & 0.56 & 0.13 & 0.70 & 0.39 \\
\hline 12 & Italy & 1.03 & 9.50 & 0.87 & 0.56 & 0.31 & 0.90 & 8.27 & 0.49 & 0.49 & 0.65 & 0.48 \\
\hline 13 & Cyprus & 0.94 & 7.60 & 0.77 & 0.51 & 0.25 & 0.72 & 5.85 & 0.39 & 0.19 & 0.59 & 0.41 \\
\hline 14 & Latvia & 1.24 & 4.63 & 0.71 & 0.67 & 0.15 & 0.88 & 3.29 & 0.48 & 0.11 & 0.68 & 0,32 \\
\hline 15 & Lithuania & 1.46 & 4.97 & 0.71 & 0.79 & 0.16 & 1.04 & 3.53 & 0.56 & 0.11 & 0.76 & 0.32 \\
\hline 16 & Luxemburgh & 1.19 & 30.87 & 0.38 & 0.65 & 1.00 & 0.45 & 11.73 & 0.25 & 0.38 & 0.57 & 0.81 \\
\hline 17 & Hungary & 1.18 & 4.23 & 0.84 & 0,64 & 0.14 & 0.99 & 3.55 & 0.54 & 0.12 & 0.70 & 0.35 \\
\hline 18 & Malta & 1.59 & 7.93 & 0.69 & 0.86 & 0.26 & 1.10 & 5.47 & 0.59 & 0.18 & 0.81 & 0.39 \\
\hline 19 & Netherlands & 1.09 & 14.33 & 0.71 & 0.59 & 0.46 & 0.77 & 10.17 & 0.42 & 0.33 & 0.62 & 0.53 \\
\hline 20 & Austria & 1.19 & 14.03 & 0.71 & 0.65 & 0.45 & 0.84 & 9.96 & 0.46 & 0.32 & 0.67 & 0.53 \\
\hline 21 & Poland & 1.27 & 4.07 & 0.78 & 0.69 & 0.13 & 0.99 & 3.17 & 0.54 & 0.10 & 0.71 & 0.32 \\
\hline 22 & Portugal & 1.12 & 6.30 & 0.87 & 0.61 & 0.20 & 0.97 & 5.48 & 0.53 & 0.17 & 0.69 & 0.40 \\
\hline 23 & Romania & 1.35 & 3.20 & 0.84 & 0.73 & 1.10 & 1.13 & 2.69 & 0.61 & 0.08 & 0.76 & 0.32 \\
\hline 24 & Slovenia & 1.11 & 6.93 & 0.79 & 0.60 & 0.22 & 0.88 & 5.47 & 0.47 & 0.17 & 0.66 & 0.39 \\
\hline 25 & Slovakia & 1.28 & 5.20 & 0.83 & 0.70 & 0.17 & 1.06 & 4.32 & 0.58 & 0.14 & 0.74 & 0.37 \\
\hline 26 & Finland & 1.11 & 13.53 & 0.64 & 0.60 & 0.44 & 0.71 & 8.66 & 0.38 & 0.28 & 0.61 & 0.50 \\
\hline 27 & Sweden & 1.23 & 15.77 & 0.41 & 0.67 & 0.51 & 0.50 & 6.47 & 0.27 & 0.21 & 0.59 & 0.48 \\
\hline 28 & England & 1.10 & 11.77 & 0.34 & 0.60 & 0.38 & 0.20 & 4.00 & 0.20 & 0.13 & 0.52 & 0.37 \\
\hline 29 & Island & 1.84 & 21.07 & 0.18 & 1.00 & 0.68 & 0.61 & 3.79 & 0.18 & 0.12 & 0.75 & 0.53 \\
\hline 30 & Lichtenstein* & - & - & - & - & - & - & - & - & - & - & - \\
\hline 31 & Norway & 1.01 & 22.37 & 0.19 & 0.55 & 0.72 & 0.19 & 4.25 & 0.10 & 0.14 & 0.41 & 0.56 \\
\hline 32 & Switzerland & 1.50 & 24.67 & 0.28 & 0.82 & 0.78 & 0.42 & 6.91 & 0.23 & 0.22 & 0.65 & 0.63 \\
\hline 33 & $\begin{array}{l}\text { Former } \\
\text { Republic of } \\
\text { Yugoslavia }\end{array}$ & 1.48 & 1.63 & 0.98 & 0.80 & 0.05 & 1.45 & 1.60 & 0.78 & 0.05 & 0.85 & 0.33 \\
\hline 34 & Albania & 1.33 & 1.33 & 0.99 & 0.71 & 0.04 & 1.32 & 1.32 & 0.70 & 0.04 & 0.80 & 0.33 \\
\hline 35 & Serbia & 1.13 & 1.73 & 0.96 & 0.61 & 0.06 & 1.08 & 1.66 & 0.59 & 0.06 & 0.74 & 0.35 \\
\hline
\end{tabular}

Note: * - data unavailable. 
The results of correlation-regression analysis can be used in the strategic planning of economic development of countries. Based on the established values of intensity, continuity and dynamics of economic development of EU countries, all countries can be divided into groups (Figures 4 and 5).

Based on Figures 4 and 5 country-specific analysis can be conducted to determine the impact of the intensity, continuity and dynamics of the economic development of groups of countries on their social, ecological and other development. The results of such analysis can

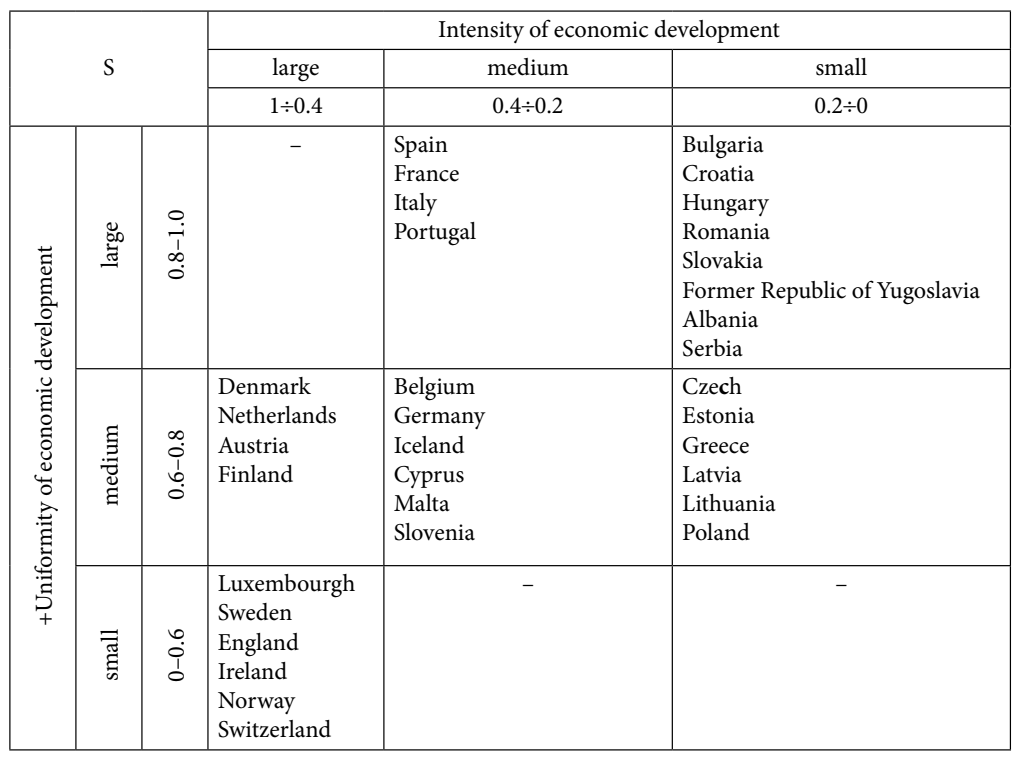

Figure 4. Matrix of EU economic development during 2008-2017 (source: compiled by the authors)

\begin{tabular}{|l|l|l|}
\hline \multicolumn{3}{|c|}{ Dynamics of economic development } \\
\hline \multicolumn{1}{|c|}{ 1level } & \multicolumn{1}{|c|}{2 level } & \multicolumn{1}{|c|}{3 level } \\
\hline \multicolumn{1}{|c|}{$0.6-0.4$} & \multicolumn{1}{|c|}{$0.4-0$} \\
\hline $\begin{array}{l}\text { Luxembourgh } \\
\text { Switzerland }\end{array}$ & Belgium & Bulgaria \\
& Denmark & Czekh \\
& Germany & Estonia \\
& Ireland & Croatia \\
& Greece & Latvia \\
& Spain & Lithuania \\
& France & Hungary \\
& Italy & Malta \\
& Cyprus & Poland \\
& Netherlands & Romania \\
& Austria & Slovenia \\
& Portugal & Slovakia \\
& Finland & England \\
& Iceland & Former Republic of Yugoslavia \\
& Norway & Albania \\
& Switzerland & Serbia \\
\hline
\end{tabular}

Figure 5. Breakdown of EU countries by the dynamics of economic development over 2008-2017 (source: compiled by authors) 
be used in strategic planning of the development of countries, in the formulation of their consecutive regional policy of countries, and so on. The methodology used is universal and can be applied to the analysis of the development of any socio-economic process.

\section{Conclusions}

1. Economic development is at the heart of the country's well-being. In order to manage this process in a consecutive way, it should be possible to quantify its condition at a desired point in time. Literature analysis has highlighted two fundamental approaches to measuring the economic status of a country. One of these proposes Gross Domestic Product per capita (GDP), and the other suggests to base it on multi-criteria approaches. By recognizing that the second approach to assessing the state of economic development may be more accurate as it can take into account all its essential aspects, the first approach is nevertheless preferred. The system of indicators is the basis for multi-criteria evaluation. Due to the specificity of countries, and the availability of relevant information it differs both in the number of indicators and in the composition. For these and other reasons, the results of the evaluation cannot be used for comparisons between countries. Meanwhile, GDP is widely recognized as one of the most important indicators of economic development. The information about it is easily accessible, and its content is applicable for international comparison.

2. Analysis of the changes in GDP per capita over individual time periods showed that the process of country's economic development can be characterized by four parameters intensity, homogeneity, dynamics and duration of the period considered. Intensity reflects upon quantitative changes in development, while continuity refers to the qualitative changes, and dynamics integrates the previous ones. The nature of their interaction has become apparent, as the intensity of economic development diminishes at the account of its continuity.

3. Developmental dynamics refers to the product or sum of the values of intensity and smoothness variables respectively if their relevance to developmental dynamics is evaluated or not evaluated. The analysis of the dynamics of economic development of the European Union countries for the years 2008-2017 was carried out according to the MDD methodology published in the scientific press. It assumes that development intensity is the ratio of the state of economic development at the end of the period under consideration to the situation at the beginning of that period. The integrity of development is the ratio of the length of the period under consideration to the actual length of the economic development trajectory. Development dynamics is the multiplication of the values of the intensity and continuity indices if their importance to the dynamics of development is non-estimated or the sum if the importance is estimated.

4. All EU countries have been divided into three levels of development based on the values of the indicators of intensity, continuity and dynamics of economic development. Only two countries - Luxembourg and Switzerland - came first, followed by 16 countries after the second and third. Such a breakdown allows for a differentiated analysis of the social, environmental, and other effects of the economic development dynamics of countries development, depending on the level of economic development achieved. 


\section{Author contributions}

All authors have the same contribution to the article.

\section{Disclosure statement}

Authors declare that they do not have any competing financial, professional, or personal interests from other parties.

\section{References}

Babu, S., \& Dutta, S. (2015). Revisiting the link between socio-economic development and environmental status indicators focus on panel data. Environment Development and Sustainability, 17(3), 567-586. https://doi.org/10.1007/s10668-014-9561-6

Becker, W., Saisana, M., Paruolo, P., \& Vandecasteele, I. (2017). Weights and importance in composite indicators: closing the gap. Ecological Indicators, 80, 12-22. https://doi.org/10.1016/j.ecolind.2017.03.056

Bilan, Y., Vasilyeva, T., Lyeonov, S., \& Bagmet, K. (2019). Institutional complementarity for social and economic development. Business: Theory and Practice, 20, 103-115. https://doi.org/10.3846/btp.2019.10

Boggia, A., \& Cortina, C. (2010). Measuring sustainable development using a multi-criteria model: a case study. Journal of Environmental Management, 91, 2301-2306. https://doi.org/10.1016/j.jenvman.2010.06.009

Boggia, A., Rocchi, L., Paolotti, L., Musotti, F., \& Greco, S. (2014). Assessing rural sustainable development potentialities using a dominance-based rough set approach. Journal of Environmental Management, 144, 160-167. https://doi.org/10.1016/j.jenvman.2014.05.021

Booysen, F. (2002). An overview and evaluation of composite indices of development. Social Indicators Research, 54(2), 115-151. https://doi.org/10.1023/A:1016275505152

Compagnolo, L., Carraro, C., Eboli, F., Farnia, L., Parrado, R., \& Pierfederici, R. (2018). The Ex-ante evaluation of achieving sustainable development goals. Social Indicators Research, 136, 73-116. https://doi.org/10.1007/s11205-017-1572-x

Delai, I., \& Takahashi, S. (2011). Sustainability measurement system: a reference model proposal. Social Responsability Journal, 7(3), 438-471. https://doi.org/10.1108/17471111111154563

Chowolhury, S., \& Squire, L. (2006). Setting weights for aggregate indices: an application to the committment to development index and human development index. Journal of Development Studies, 42(5), 761-771. https://doi.org/10.1080/00220380600741904

Čiegis, R., Ramanauskienė, J., \& Šimanskienè, L. (2010). Lietuvos regiony darnaus vystymosi vertinimas. Klaipedos universiteto leidykla.

Gedvilaite, D. (2019). The assessment of sustainable development of a country's regions. Technika.

Golusin, M., Munitlak, O. I., \& Teodorovic, N. (2011). The review of the achieved degree of sustainable development in South Eastern Europe - the use of linear regression method. Renewable and sustainable Energic Reviews, 15, 766-772. https://doi.org/10.1016/j.rser.2010.07.064

Graymore, L. M., Sipe, N. G., \& Rickson, R. E. (2010). An index of regional sustainability: A GIS-based multicretiria analysis decision support system for progressing sustainability. Ecological Complexity, 6(4), 453-462. https://doi.org/10.1016/j.ecocom.2009.08.006 
Ginevičius, R., Gedvilaite, D., Stasiukynas, A., \& Šliogerienè, J. (2018). Quantitative assessment of the dynamic of the economics development of socioeconomic systems based on the MDD method. Inzinerine ekonomika - Engineering Economics, 29(3), 531-553. https://doi.org/10.5755/j01.ee.29.3.20444

Gzzebyk, M., \& Stec, M. (2015). Sustainable development in EU countries: concept and ratiny of levels of development. Sustainable Development, 23, 110-123. https://doi.org/10.1002/sd.1577

Hamilton, C. (2007). Measuring sustainable economic welfare. Edward Elgar Publishing. https://doi.org/10.4337/9781847205223.00030

Janker, J., \& Mann, S. (2018). Understanding the social dimension of sustainability in agriculture: a critical review of sustainability assessment tools. Environment, Development and Sustainability, 22, 1671-1691. https://doi.org/10.1007/s10668-018-0282-0

Jia, X., Foo, D. C. Y., Tan, R. R., \& Li, Z. (2017). Sustainable development paths for resource - constrained process industries. Resources, Conservation and Recycling, 119, 1-13. https://doi.org/10.1016/j.resconrec.2016.11.004

Eurostat. (2019). Main GDP aggregates. https://ec.europa.eu/eurostat/web/products-datasets/product? code $=$ namq_10_pc

Eurostat. (n.d.). www.eurostat.com

Ivanovic, O. D. M., Golusin, M. T., Dpplic, S. N., \& Doolic, T. J. M. (2009). Perspectives of sustainable development in countries of South Eastern Europe. Renewable and Sustainable Energy Reviews, 13, 2074-2087. https://doi.org/10.1016/j.rser.2009.03.004

Kareivaite, R. (2012). Kompleksinis darnaus vystymosi vertinimas taikant daugiakreiterinius metodus (Daktaro disertacija). Vytauto Didžiojo universitetas.

Kondyli, J. (2010). Measurement and evaluation of sustainable development - a composite indicator for the Islands of the North Aeglan region, Greece. Environemental Impact Assessment Review, 30, 347-356. https://doi.org/10.1016/j.eiar.2009.08.006

McLaren, D., Bullock, S., \& Yousef, N. (1998). Tommorow's world: Britain's share in a sustainable future. Routledge.

Mally, K. M. (2018). Regional differences in Slovenia from the viewpoint of achieving Europe's sustainable development. Acta Geographica Slovenia, 58(2), 2-46. https://doi.org/10.3986/AGS.3309

Parris, T. M., \& Kates, R. W. (2003). Characterizing and measuring sustainable development. Annual Review of Environment and Resources, 28(13), 1-28. https://doi.org/10.1146/annurev.energy.28.050302.105551

Pehlivan, N. Y., Sahin, A., Zavadskas, E. K., \& Turskis, Z. (2018). A comparative study of integrated FMCOM methods for evaluation of organizational strategy development. Journal of Business Economics and Management, 19(2), 360-381. https://doi.org/10.3846/jbem.2018.5683

Prascevic, N., \& Prascevic, Z. (2017). Application of fuzzy AHP for ranking and selection of alternatives in construction project management. Journal of Civil Enegineering and Management, 23(8), 1123-1135. https://doi.org/10.3846/13923730.2017.1388278

Radovanovic, M., \& Lior, M. (2017). Sustainable economic-environmental planning in South East Europe-beyond-GDP and climate change emphases. Sustainable Development, 25, 580-594. https://doi.org/10.1002/sd.1679

Rametsteiner, E., Alkan-Olsson, H. P. J., \& Frederiksen, P. (2011). Sustainability indicator developmentscience or political negotiation? Ecological Indicators, 11, 61-70.

https://doi.org/10.1016/j.ecolind.2009.06.009

Rogge, N. (2018). Composite indicators as generalizes benefit-of-the-doubt-weighted averages. European Journal of Operational Research, 267(1), 381-392. https://doi.org/10.1016/j.ejor.2017.11.048 
Rotmans, J. (2006). Tools for integrated sustainability assessment: a tow track approach. The Integrated Assessment Journal Bridging Sciences \& Policy, 6(4), 35-57.

Sala, S., Ciuffo, B., \& Nijkamp, P. (2015). A systemic framework for sustainability assessment. Ecological Economics, 114, 314-325. https://doi.org/10.1016/j.ecolecon.2015.09.015

Scherp, J. (1994). What does an economist need to know about the environment? Directorate-General for E economic and E - financial Affairs. Economic Papers of the European Commission, No. 107.

Schoenaker, N., Hoekstra, R., \& Smits, J. (2015). Comparison of measurement systems for sustainable development at the national level. Sustainable Development, 23, 285-300. https://doi.org/10.1002/sd.1585

Song, Y., Yao, S., Yu, D., \& Schen, Y. (2017). Risky multi-criteria group decision on green capacity investment projects based on supply chain. Journal of Business Economics and Management, 18(3), 355-372. https://doi.org/10.3846/16111699.2017.1331461

Spangenberg, J. H. (2012). Institutional sustainability indicators: an analysis of the institutions in Agenda 21 and a draft set of indicators for monitoringtheir effectivity. Sustainable Development, 10(2), 103-115. https://doi.org/10.1002/sd.184

Strezov, V., Evens, A., \& Evans, T. J. (2017). Assessment of the economic, social and environmental dimensions of the indicators for sustainable development. Sustainable Development, 25(3), 242-253. https://doi.org/10.1002/sd.1649

Touceda, M. Y., Neila, F., J., \& Degrez, M. (2018). Modeling socioeconomic pathways to assess sustainability: a tailored development for housing retrifit. The International Journal of Life Cycle Assessment, 23(3), 710-725. https://doi.org/10.1007/s11367-016-1194-6

Turan, C. (2013). Re-thinking sustainability indicators: local perspectives of urban sustainability. Journal of Environmental Planning and Management, 56(5), 695-719. https://doi.org/10.1080/09640568.2012.698984

Turskis, Z., Morkūnaite, Z., \& Kutut, V. (2017). A hybrid multiple criteria evaluation method of ranking of caltural heritage strucrues for renovation projects. International Journal of Strategic Property Management, 21(3), 318-329. https://doi.org/10.3846/1648715X.2017.1325782

Van den Beryh, J. C. J. M. (2009). The GDP paradox. Journal of Economic Psychology, 30, 117-135. https://doi.org/10.1016/j.joep.2008.12.001

Zhou, P., Ang, B. W., \& Zhou, D. Q. (2010). Weighting and aggregation in composite indicator construction: a multiplicative approach. Social Indicators Research, 96(1), 169-181. https://doi.org/10.1007/s11205-009-9472-3

Zinatizadeh, S., Azmi, A., Monavari, S. M., \& Sobhanazdakani, S. (2017). Evaluation and prediction of sustainaility of urban areas: a case study for Kermanshahsity, Iran. Cities, 66, 14. https://doi.org/10.1016/j.cities.2017.03.002

Xavier, A., Costa Freitas, M. B., Fragoso, R., \& Rosário, M. D. S. (2018). A regional composite indicator for analysing agricultural sustainability in Portugal: a goal programming approach. Ecological Indicators, 89, 84-100. https://doi.org/10.1016/j.ecolind.2018.01.048

Wackernagel, M., \& Rees, W. E. (1996). Ecological footprints and appropriated carrying capacity. Measuring the natural capital requirements of the human economy. Focus, 6(1), 45-60.

Wallis, A. M., Graymore, L. M., \& Richards, A. J. (2011). Significance of environment in the assessment of sustainable development: the case of south west Victoria. Ecological Economics, 70(4), 545-605. https://doi.org/10.1016/j.ecolecon.2010.11.010

Wang, J., Wei, X., \& Guo, Q. (2018). A three-dimensional evaluations for regional carrying capacity of ecological environment to social economic development: model development and a case study in China. Ecological Indicators, 89, 348-355. https://doi.org/10.1016/j.ecolind.2018.02.005 